\title{
National Identification and Attitudes Towards Russian Immigrants in Finland: Investigating the Role of Perceived
} Threats and Gains

\section{Brylka, Asteria}

\section{5-12}

Brylka , A , Mähönen , T A \& Jasinskaja-Lahti , I 2015 , ' National Identification and Attitudes Towards Russian Immigrants in Finland: Investigating the Role of Perceived Threats and Gains ', Scandinavian Journal of Psychology , vol. 56 , no. 6 , pp. 670-677 . https://doi.org/10.1111/sjop.12242

http://hdl.handle.net/10138/234345

https://doi.org/10.1111/sjop.12242

acceptedVersion

Downloaded from Helda, University of Helsinki institutional repository.

This is an electronic reprint of the original article.

This reprint may differ from the original in pagination and typographic detail.

Please cite the original version. 
Accepted author manuscript.

Brylka, A., Mähönen, T. A., \& Jasinskaja-Lahti, I. (2015).

National identification and attitudes towards Russian immigrants in Finland: investigating the role of perceived

threats and gains. Scandinavian journal of psychology, 56(6), 670-677.

National Identification and Attitudes Towards Russian Immigrants in Finland:

Investigating the Role of Perceived Threats and Gains

Scandinavian Journal of Psychology (in press)

Asteria Brylka*, Tuuli Anna Mähönen, \& Inga Jasinskaja-Lahti

Word count for the abstract: 138

Word count for the main text: 5355

Word count for the references: 1246

Word counts for the tables: 322

Word count for figures: 39

Number of tables: 3

Number of figures: 2 


\begin{abstract}
In this cross-sectional study, we examined the relationship between national identification of majority Finns (nation-wide probability sample, $N=335$ ) and their attitudes towards Russian immigrants living in Finland. As previous research indicates both possibilities, we tested whether this relationship was moderated or mediated by threats and gains perceived to result from immigration. The results supported the mediation hypothesis; those individuals who identified stronger with their national ingroup perceived more threats than gains related to increased immigration and these perceptions, in turn, were associated with more negative attitudes towards immigrants. The role of realistic as opposed to symbolic threats and gains was particularly pronounced. The implications of the results are discussed in terms of their theoretical relevance and practical means to improve intergroup relations, with a particular focus on the relations between Finns and Russian immigrants in Finland.
\end{abstract}

Keywords: outgroup attitudes, immigrants, national identification, perceived threats and gains, intergroup relations 
National Identification and Attitudes Towards Russian Immigrants in Finland: Investigating the Role of Perceived Threats and Gains

Growing ethno-cultural diversity is one of the greatest social challenges faced by contemporary societies, and research-based information about the determinants of harmonious intergroup relations is much needed - especially in European nation states struggling to balance between national preservation and immigrant integration (e.g., Van Reekum, Duyvendak, \& Bertossi, 2012). The changes caused by increasing immigration are particularly salient in societies that, until recently, were not considered immigrant destination countries and were, thus, relatively ethnically homogenous.

One such is Finland, for decades a country of emigration (Pitkänen \& Kouki, 2002), but for the last two decades facing a steady increase in the number of immigrants (Statistics Finland, 2014). At the moment, the number of foreign nationals in Finland has exceeded 289000 (i.e., $5.3 \%$ of the total population), with Russian speakers being the largest immigrant group both in the scope of the whole country (Statistics Finland, 2014) and the capital area (Simoila, Väistö, Nyman, \& Niemelä, 2011).

Because of the relatively conflictual history between Finland and the former Soviet Union, intergroup relations between the Finnish majority and the Russian immigrants are far from being smooth (Puuronen, 2011). This is reflected, for instance, in the constantly negative attitudes of Finns towards Russian immigrants and the low position of this group in the Finnish ethnic hierarchy (Jaakkola, 2009), as well as discrimination and employment difficulties (Larja et al., 2012). 
In the present study, we approach the intergroup relations between the Finnish majority and the Russian immigrants from the perspective of social identity theory (SIT; Tajfel \& Turner, 1979) and integrated threat theory (ITT; Stephan \& Stephan, 2000). Specifically, we investigate the role of perceived intergroup threats and gains (Stephan \& Stephan, 2000; Stephan, Renfro, \& Davis, 2008; Mähönen, Jasinskaja-Lahti, Liebkind, \& Finell, 2011) in the relationship between majority Finns' national identification and attitudes towards Russian immigrants living in Finland.

The Social Identity Theory and the Integrated Threat Theory Approach

\section{Interplay Between National Identification, Outgroup Attitudes, and Threat Perceptions}

In the social psychology of intergroup relations, ingroup identification and intergroup threat are often studied in connection to outgroup attitudes. Previous research has been mainly conducted along the lines of either SIT (Tajfel \& Turner, 1979) or ITT (Stephan \& Stephan, 2000). These theories, however, offer different views on the role of perceived intergroup threat in the relationship between ingroup identification and outgroup attitudes. While in SIT (Tajfel \& Turner, 1979), perceived intergroup threat is treated as a moderator of the relationship in question, in ITT (Stephan \& Stephan, 2000) it acts as a mediator between ingroup identification and attitudes towards outgroup members. In research building on the assumptions of SIT (Tajfel \& Turner, 1979), identification with social groups is seen as a source of ingroup favouritism as well as, often, of outgroup derogation and negative attitudes towards members of relevant social outgroups. Although some studies within the SIT paradigm have questioned the direct relationship between 
ingroup identification and discrimination of outgroups or argued for the reciprocal nature of this relationship (see e.g., Turner \& Reynolds, 2001), many studies have nevertheless demonstrated that individuals who identify strongly with their ingroup show less positive attitudes towards outgroup members (Hodson, Dovidio, \& Esses, 2003; Mummendey, Klink, \& Brown, 2001; Reynolds et al., 2007). In addition, this negative relationship between ingroup identification and outgroup attitudes is expected to be stronger under conditions of realistic and symbolic threats subjectively perceived on behalf of the ingroup (Tajfel \& Turner, 1979).

So far only a few studies have examined the joint effect of national identification and perceived threats on attitudes towards cultural and religious outgroups (Branscombe \& Wann, 1994; Tausch, Tam, Hewstone, Kenworthy, \& Cairns, 2007), or specifically towards immigrants (Bizman \& Yinon, 2001a\&b). The obtained results have raised further questions on the nature of the investigated relationship, as depending on the social and societal context studied either symbolic (Branscrombe \& Wann, 1994; Tausch et al., 2007) or realistic threats (Bizman \& Yinon, 2001a, 2001b) have emerged as more important.

ITT (Stephan \& Stephan, 2000) — the other key theorisation on the association between ingroup identification, perceived intergroup threat, and outgroup attitudes — builds on the legacy of realistic conflict theory (RCT; LeVine \& Campbell, 1972; Sherif, 1966) and treats ingroup identification as an antecedent of various intergroup threats (i.e., realistic and symbolic threat, intergroup anxiety, and negative stereotypes). In other words, high ingroup identification is thought to make the individual perceive more threats, which, in turn, lead to more negative outgroup attitudes. 
Similar to the SIT framework (Tajfel \& Turner, 1979), in this model realistic threats refer to threats to the existence or well-being of the ingroup, while symbolic threats concern threats to the ingroup's worldview and standards of conduct. The mediating role of realistic and/or symbolic threats in the relationship between ingroup identification and outgroup attitudes has been demonstrated in a few recent studies (e.g., Aberson \& Gaffney, 2009; Stephan et al., 2002; Velasco González, Verkuyten, Weesie, \& Poppe, 2008). These studies have found that higher national identification enhances the perception of intergroup threats, which in turn lead to less positive attitudes towards outgroup members.

\section{Practical Implications of the Moderating Versus Mediating Role of Threat}

\section{Perceptions}

As reviewed above, SIT and ITT attribute different roles to threat perceptions in the relationship between national identification and outgroup attitudes. Identifying whether the relationship is negative for only those who perceive high levels of threat (moderation) or for all individuals (mediation) is crucial, not only for gaining a better understanding of but also improving intergroup relations in plural societies.

Specifically, programs aimed at prejudice reduction among majority group members can be successful only when the perception of immigration-related threats is properly addressed by an intervention.

A moderating role of perceived threats in the relationship between national identification and outgroup attitudes would mean that even strong national identification of majority group members is not necessarily detrimental for attitudes towards immigrants. Specifically, stronger national identification would predict more hostile attitudes toward newcomers only for those majority group members who strongly feel that immigration threatens the ingroup. Thus, in the case of the 
moderating role of perceived threats, interventions aimed at prejudice reduction towards immigrants could focus solely on downplaying threat perceptions rather than, for example, on regulating the degree and/or content of national identification.

A mediating role of threats in the association between national identification and outgroup attitudes would, in turn, have different theoretical and practical implications for intergroup relations. In this case, stronger national identification would be linked to a stronger perception of threats which, in turn, would be associated with more negative outgroup attitudes. Therefore, when threat is a mediator of the relationship in question, interventions should focus on promoting a more inclusive national identity and more positive views on immigration, or on possible moderators of the link between the perceptions of threats and outgroup attitudes. For instance, the aim of such interventions could be strengthening the feeling of security among majority members; in this case, the perception of even more immigration-related threats would not trigger defensive or hostile reactions towards immigrants.

\section{Extending the Frameworks of Social Identity Theory and Integrated Threat Theory}

\section{Perceived Gains}

Notably, research on intergroup relations in general and immigration in particular has almost solely focused on perceived threats, overlooking the role of perceived benefits or gains in the formation of majority members' outgroup attitudes. This is surprising, given the calls for research that would not only investigate the causes of negative intergroup relations but also aim to promote positive contact and 
social inclusion (see e.g., Esses, Jackson, Dovidio, \& Hodson, 2005; Tropp \& Mallett, 2011).

To the best of our knowledge, the association between perceived gains to result from immigration and outgroup attitudes was previously examined only by Meeus, Duriez, Vanbeselaere, Phalet, and Kuppens (2009) and Mähönen et al. (2011). In both studies, perceived gains were conceptualised by analogy with the ITT approach to threats (Stephan \& Stephan, 2000; Stephan et al., 2008); perceived symbolic gains referred to benefits to the cultural life of the host society and perceived realistic gains referred to benefits for society's economy. The findings of the studies were, however, contradictory. Meeus and colleagues (2009) found gains perceived to result from Polish immigration to the Netherlands were not associated with Dutch people's attitudes towards this immigrant group. Mähönen and colleagues (2011), in turn, found that symbolic gains perceived to result from Russian immigration to Finland were associated with more favourable explicit attitudes towards these immigrants, and that perceived realistic gains were associated with more negative implicit attitudes. The latter was explained so that the perceived gains often associated with labour migration may have increased awareness of majority group members concerning the economic competition between host nationals and immigrants.

\section{Personal and Group Threats and Gains}

In addition, both in the original formulation of ITT (Stephan \& Stephan, 2000) and in its later development (Stephan et al., 2008), it is acknowledged that intergroup threats can be perceived at both personal and group levels. As SIT (Tajfel $\&$ Turner, 1979) proposes that personal identity triggers inter-individual reactions and social identity triggers intergroup reactions, it is reasonable to assume that 
personal and group-related threats may be differently associated with ingroup identification and attitudes towards outgroups. In particular, since perceived grouprelated threats refer to the whole national ingroup, it can be expected that under this threat condition the relationship between national identification and outgroup attitudes is stronger than if personal threats are perceived.

Therefore, we incorporate the theoretical distinction between personal and group-related threats to the present study. We define threats as personal when they refer to resource deprivation, material harm, or harm to the individual's identity or self-esteem, and as group when they threaten power, welfare, undermine the culture, religion, or general worldview of the ingroup. Following this distinction, we similarly differentiate between personal versus group gains, as it is possible that some gains are more easily perceived from the viewpoint of the ingroup (e.g., positive effects on national economy) or oneself (e.g., increased ability to understand other cultures). Thus, we define gains as personal when they refer to the improvement of the individual's economic status, personal safety or access to services, or when they increase the understanding of other cultures and broaden cultural horizons of the individual. Group gains, in turn, refer to the enforcement of power and welfare of host society, and the enrichment of the cultural, religious, and everyday life in the whole country.

Given the previous findings pointing to perceived threats (e.g., Tausch et al., 2007; Velasco González et al., 2008) but also gains (Mähönen et al., 2011) associating with majority members' attitudes towards immigrants, in the present study, we investigate the relationship between national identification and outgroup attitudes and the role of immigration-related threats and gains in the formation of this association. We recognise that, among members of the national majority, 
immigration may simultaneously elicit the perception of both threats and gains, and these perceptions are weighed against each other. While some individuals perceive more threats than gains to result from immigration, others perceive more gains than threats or an equal amount of both. It is reasonable to expect that a negative association between national identification and outgroup attitudes may be due to the overemphasised perception of threats over gains (mediation) and that it is relational importance of gains over threats that may attenuate the negative effect of national identification on outgroup attitudes (moderation). Thus, we argue that they should be examined in relation to each other.

In previous research, threats and gains have been approached either as simultaneous and qualitatively different evaluations, or as inversely related. While some researchers have argued that negative and positive evaluations should be distinguished from one another in a bivariate space (e.g., Cacioppo, Garder, \& Berntson, 1997), other studies (e.g., Alhakami \& Slovic, 1994) have empirically shown that judgments of risks and benefits are inversely related. This inverse association between risk and benefit evaluations is linked to the confounding of risk and benefit in people's minds, which forms the basis for an individual's overall evaluation of an attitude object (Alkahami \& Slovic, 1994).

We posit here that due to the complexity of the phenomenon of immigration and ambivalent attitudes attached to it, the assessment of immigration-related risks (threats) and benefits (gains) is likely to elicit the confounding of these negative and positive evaluations among members of the national majority group. As a result, immigration-related threats and gains will be evaluated in relation to each other, and the overall evaluation will reflect how individuals altogether weighed positive and negative aspects of immigration. 


\section{Aim and Hypotheses of the Study}

This study aims to clarify the nature of the relationship between national identification, threats and gains perceived to result from immigration, and majority members' attitudes towards immigrants. Therefore, we examine two competitive but equally plausible models of the relationship in question, namely, the moderation model supported by assumptions of SIT (Tajfel \& Turner, 1979) and the mediational model proposed by ITT (Stephan \& Stephan, 2000). A similar methodological approach to test both moderation and mediation has previously been used in the study of Meeus, Duriez, Vanbeselaere, and Boen (2010) who examined two competitive but theoretically plausible models of the association between national identification, civic and ethnic representations of national identity, and outgroup attitudes.

In the first model, based on SIT (Tajfel \& Turner, 1979), we posit that the relationship between national identification and outgroup attitudes among majority Finns is moderated by the perception of intergroup threats and gains resulting from Russian immigration to the country. In the second, model, based on ITT (Stephan \& Stephan, 2000), we propose that the perception of intergroup threats and gains resulting from Russian immigration to Finland mediates the relationship between national identification and outgroup attitudes among majority Finns. Both models are visualised in Figure 1. The moderation hypothesis will be supported if there is a stronger association between high national identification and negative outgroup attitudes for those who perceive more threats than gains to result from immigration, as compared to those who perceive more immigration-related gains than threats (Hypothesis 1). The alternative mediation hypothesis will be supported if high national identifiers tend to perceive more threats than gains when compared to low 
national identifiers, and if these threats over gains perceptions further lead to more negative attitudes towards immigrants (Hypothesis 2). We adjust for the effects of gender, age, and years of education in our analysis, as previous research in the same intergroup context has found these socio-demographic variables to be associated with majority members' outgroup attitudes (e.g., Jaakkola, 2009).

Figure 1 about here

Depending on the results obtained for Hypotheses 1 and 2, we will investigate in post-hoc analysis whether the pattern of results differs when a distinction is made between (1) personal versus group and (2) realistic versus symbolic threats and gains. Regarding the first distinction, SIT (Tajfel \& Turner, 1979) offers solid foundations for expecting the association between national identification and outgroup attitudes to be strongly affected by the perception of group — but not personal — threats and gains. Thus, we expect that the association between national identification, group threats and gains, and outgroup attitudes of majority Finns will be stronger than when personal threats and gains are involved (Hypothesis 3).

As regards the distinction between realistic and symbolic threats and gains, previous research (Bizman \& Yinon, 2001a, 2001b; Branscrombe \& Wann, 1994; Tausch et al., 2007) has shown that the association between national identification and perceived realistic and symbolic threats depends on the national context in question. While a study on Israeli majority group members found an interaction between national identification and realistic (but not symbolic) threats (Bizman \& Yinon, 2001a, 2001b), a study on Catholics and Protestants in Northern Ireland found an interaction only between national identification and symbolic (but not realistic) threats (Tausch et al., 2007). Therefore, it is plausible that, in the Finnish 
national context, realistic and symbolic threats and gains can also be differently associated with majority members' national identification and outgroup attitudes. However, the lack of previous research on threats and limited research on gains in Finland (see Mähönen et al., 2011) does not allow us to make any specific hypotheses about the different roles of realistic and symbolic threats and gains in the relationship between national identification and outgroup attitudes of majority Finns. Thus, we only explore the possibility of different effects of realistic and symbolic threats and gains on the relationship in question.

\section{Method}

\section{Participants and Procedure}

This study was carried out as part of the international project Mutual Intercultural Relations in Plural Societies (MIRIPS), coordinated by John Berry (Berry, 2012). Data was collected through a postal survey between June and September 2012 among a representative sample of 1000 Finnish-speaking majority Finns ${ }^{1}$ drawn by the Finnish National Population Register Centre. To ensure that the sampling was correct, the ethno-linguistic background of the participants was additionally checked with a question about their parents' ethno-cultural background (Finnish/other) and mother tongue (Finnish). Participation in the study was voluntary and confidential. The response rate of 33.5 per cent $\left(N=335 ; 57 \%\right.$ female, $M_{\text {age }}=$ 45.9, $\left.S D_{\text {age }}=13.8\right)$ can be considered to be less than optimal, but it is typical of survey studies with representative samples conducted in Finland. The final sample of the present study was still regionally representative, but not representative in terms of gender and age (mean age of non-respondents 41.1 years, $S D_{\text {age }}=13.4$ ).

\footnotetext{
${ }^{1}$ In Finland there are two official languages: Finnish, spoken by the vast majority of Finns (93\%), and Swedish, spoken by around $6 \%$ of Finnish nationals.
} 


\section{Measures}

National identification was measured with a four-item scale adapted from Mlicki and Ellemers (1997) and Phinney and Devich-Navarro (1997) (see also Berry, Phinney, Sam, \& Vedder, 2006 or Meeus et al., 2010). The items covered the cognitive (e.g., "I think of myself as being Finnish") and affective (e.g., "I am proud of being Finnish") aspects of national identity as well as commitment to it (e.g., "It is important to me to be Finnish"). The participants were asked to mark their answers on a five-point scale ranging from one (completely disagree) to five (completely agree $)(\alpha=.87)$. Higher scores obtained by an individual on the scale denote higher national identification.

Outgroup attitudes towards Russian immigrants were measured with an eight-item scale previously used in the present intergroup context by JasinskajaLahti, Liebkind, and Solheim (2009). Sample items include "I think that Russian immigrants are annoying" (item reversed) or "I think that Russian immigrants are just as nice as Finns". The respondents assessed the statements with a five-point scale ranging from one (completely disagree) to five (completely agree) $(\alpha=.92)$. Higher scores indicate more positive attitudes towards Russian immigrants in Finland.

Perceived threats and gains resulting from Russian immigration to Finland were measured with a twelve-item five-point bipolar scale. The definitions of threats and gains were based on the distinction made by Stephan and colleagues (2008) and the bipolar form of the scale was adapted from Schwartz (2007). The items measured the degree to which the participants perceived immigration from Russia to Finland to result in different types of (1) personal vs. group and (2) realistic vs. symbolic threats and gains related to, for example, the labour market, access to services, Finnish 
cultural life, or Finnish identity. The items tapping group threats and gains concerned the national ingroup as a whole ("Russian immigration to Finland threatens Finnish workplaces/creates new workplaces in Finland" or "Russian immigration to Finland threatens the Finnish way of living/enriches the Finnish way of living"), whereas the items tapping personal threats and gains concerned the life, family, and daily experiences of the respondent him-/herself ("Russian immigration to Finland threatens/improves my or my family's safety" or "Russian immigration to Finland threatens/improves my understanding of other cultures"). The response scale for all items ranged from minus two to two. While values under zero mean that participants perceived more threats than gains, values above zero correspond to participants' perception of gains over threats. Values equalling zero mean that participants perceived an equal amount of threats and gains. An overall index score for perceived threats and gains - the threats/gains index score, reflecting a relative difference between threats and gains perceived to result from Russian immigration to Finlandwas computed by summing individual scores on 12 items. A positive index score indicates that more gains than threats resulting from Russian immigration to Finland were perceived, whereas a negative index score indicates that a participant perceived more threats than gains. Index scores for realistic vs. symbolic and personal vs. group threats and gains were computed accordingly.

\section{Analytical Procedure}

Missing data on all variables used in this study were imputed using the hot deck method (e.g., Myers, 2011), which replaces a missing item value of the recipient with a value of the matching donor within the same dataset. The hypotheses about moderation and mediation were both tested according to the method described by Hayes (2013) using the PROCESS tool for SPSS. The conditional effect in the 
moderator model, and the direct and indirect effects in the mediator model were estimated by using an ordinary least squares regression-based path analytical framework. According to Hayes (2013), this method is more suitable for smaller data sets with variables deviating from a normal distribution than structural equation modelling (SEM) with latent variables, as it provides more accurate estimations of $p$ values for the regression coefficients. A non-parametric bootstrapping method using 10,000 resamples was used for unbiased assessing of the strength and significance of the conditional and indirect effects (e.g., Preacher, Rucker, \& Hayes, 2007). All regression coefficients in the study are reported in an unstandardised form $(B)$.

Following Hayes' (2013) procedure, the conditional effect of national identification on outgroup attitudes dependent on perceived threats and gains was estimated by regressing outgroup attitudes (DV; dependent variable) on all control variables, national identification (IV; independent variable), the threats/gains index score (Mo; moderator), and the interaction term of national identification and the threats/gains index score (IV*Mo). Prior to the moderation analysis, both the national identification and the threats/gains index score variables were centred around their respective means. In the analyses, we controlled for the effects of gender $(0=$ male $)$, age, and years of education.

The direct and indirect effects of national identification on outgroup attitudes were estimated by three regression analyses. First, the threats/gains index score (Me; mediator) was regressed on national identification and the control variables. Second, outgroup attitudes were regressed on national identification, the threats/gains index score, and the control variables. To assess the total effect of national identification on outgroup attitudes - that is, when the mediating variable is not in the model — in the third regression analysis outgroup attitudes were regressed on all control variables 
and national identification. The three models were estimated also without the control variables, and the pattern of results remained the same.

\section{Results}

\section{Descriptive Results}

The descriptive statistics of years of education, national identification, threats/gains index scores, and outgroup attitudes, as well as bivariate correlations between these variables are presented in Table 1. The participants indicated, overall, strong Finnish identification and rather positive outgroup attitudes. On average, participants perceived more personal and group gains than threats; they also perceived more symbolic gains than threats but more realistic threats than gains. All threats/gains index scores correlated strongly and positively with one another and with outgroup attitudes. Years of education correlated positively with outgroup attitudes as well as with all the threats/gains index scores, meaning that more educated individuals had more positive attitudes towards Russian immigrants and perceived more gains than threats to result from Russian immigration. Stronger national identification was associated with perceiving more threats than gains, and with more negative outgroup attitudes.

Table 1 about here

\section{Results of the Mediation and Moderation Analyses}

As regards the proposed moderation effect, the interaction between national identification and the perception of threats and gains was statistically non-significant $(B=0.16, p=.182)$, thus disconfirming Hypothesis 1 . Instead, national identification and perceived threats and gains had direct effects on outgroup attitudes. That is, 
those participants who identified more strongly with Finns and those who perceived more gains in relation to threats evaluated Russian immigrants more positively.

Table 2 about here

The mediation Hypothesis 2, in turn, was supported. The results showed that majority Finns' national identification indirectly partly influenced attitudes towards Russian immigrants via threats and gains perceived to result from Russian immigration to Finland (see Table 3). The more strongly participants identified with Finns, the more immigration-related threats they perceived as compared to gains. This perception, in turn, was associated with more negative outgroup attitudes. A bias-corrected bootstrap confidence interval (CI) $95 \%(-0.272,-0.069)$ for the indirect effect $B=-0.16$ indicated that the indirect effect was statistically different from zero. In addition, national identification was associated with outgroup attitudes directly: $B=-0.19, p=.006$. This direct relationship was, however, weaker when compared to the relationship between national identification and outgroup attitudes when perceived threats and gains were not included in the model $(B=-0.35, p$ $<.001)$.

Table 3 about here

\section{Post-Hoc Analyses}

Due to the use of correlational data, we also tested an alternative model with national identification as a mediator of the relationship between the perception of immigration-related threats and gains and attitudes towards immigrants. While the analysis also supported the alternative indirect path of $B=0.04$, CI 95\% (0.013, 0.074), the path was weaker than the indirect path found in the primary analysis. 
Another post-hoc analysis was performed by using the parallel multiple mediator model (Hayes, 2013) with two mediators. The first tested model included national identification as the independent variable, perceived personal and group threats and gains as two separate mediators, and outgroup attitudes as the dependent variable. Accordingly, in the model tested secondly, the two separate mediators were perceived realistic and symbolic threats and gains. Models tested in the post-hoc analysis are displayed in Figure 2.

Figure 2 about here

The results supported the pattern of results obtained in the primary analysis. Namely, the indirect effect of national identification on outgroup attitudes was statistically different from zero via both perceived personal $B=-0.055$, CI $95 \%$ $(-0.133,-0.012)$ and group threats and gains $B=-0.102$, CI 95\% $(-0.205,-0.039)$. There was, however, no statistically significant difference between these two indirect effects as shown by the statistically non-significant contrast test of $B=0.047, \mathrm{CI}$ $95 \%(-0.029,0.170)$, and thus, Hypothesis 3 was not supported. The indirect effects of national identification on outgroup attitudes were statistically significant through both perceived realistic $B=-0.116$, CI 95\% $(-0.216,-0.058)$ and symbolic threats and gains $B=-0.052$, CI $95 \%(-0.121$ to -0.014$)$. Further, the indirect effect via realistic threats and gains was significantly stronger than the indirect effect via symbolic threats and gains (contrast test: $B=-0.065$, CI 95\% $(-0.170,-0.001)$.

\section{Discussion}

In this study, we aimed to extend previous research on the link between ingroup identification and outgroup attitudes by investigating the role of perceived threats and gains in this association. The results showed that threats and gains 
perceived to result from Russian immigration to Finland mediated but did not moderate the relationship between Finnish majority members' national identification and their attitudes towards Russian immigrants. Put more specifically, stronger national identification was associated with more perceived immigration-related threats than gains, which, in turn, were further associated with more negative outgroup attitudes. This finding is in line with the assumptions of ITT (Stephan \& Stephan, 2000) and previous empirical research based on this theoretical framework (e.g., Aberson \& Gaffney, 2009; Stephan et al., 2002; Velasco González et al., 2008). The pattern of results found in the primary analysis remained consistent and significant regardless of whether immigration-related perceived threats and gains were examined jointly or as personal vs. group and realistic vs. symbolic. Therefore, high national identification among majority Finns seems to be associated with more prejudiced attitudes towards Russian immigrants due to stronger perceptions of all types of threats over gains. It is worth noting, however, that in the case of realistic and symbolic threats and gains, the mediating effect of the former type of threats and gains was significantly stronger than the mediating effect of the latter ones. This indicates that in Finland, which has the longest national border with Russia among all EU member states, and in its social context, threats (and gains) related to society's economy and security may be of stronger importance for intergroup relations. This may be particularly true in times of economic recession (see e.g., Heinmueller \& Hiscox, 2007) and mistrust in the relations between the EU and the Russian Federation (Engelbrekt \& Nygren, 2014, 77) when the data for this study was gathered.

Results obtained in the present study carry practical implications for majorityminority relations in Finland and potentially other diverse societies. The need for 
such interventions in Finland is increasing due to the rising number of the Russianspeaking immigrants in the country. Although Russian-speaking immigrants have a more favourable position in Finnish society than some other, even less accepted immigrant groups (e.g., Somalis) (European Union Agency for Fundamental Rights, 2012), no substantial improvement has been seen throughout the years in either their position in the ethnic hierarchy or in majority members' attitudes towards them (Jaakkola, 2009).

The results obtained in this study clearly indicate that, in order to improve attitudes towards immigrants, members of the national majority need to feel secure in the intergroup context. However, they also suggest that targeting the perception of threats directly to make them less salient does not seem to be a promising path in improving majority-minority relations. The finding that stronger national identification is linked to more a pronounced perception of immigration-related threats over gains suggests another possible route to prejudice reduction; however, the improvement of outgroup attitudes by virtue of lowering the strength of majority group's national identification may not be the preferred solution. Instead, moderating the link between national identification and the perception of threats and gains with interventions changing the representation of national identification from an ethnic to a more inclusive, civic one (Smith, 2001; see also Meeus et al., 2010) could prove useful. With such an intervention, the association between stronger national identification and the subsequent perception of immigration-related threats over gains could change. At the same time, strong but civic national identification could potentially elicit a more equalised perception of threats and gains, which would not increase prejudice towards immigrants. 


\section{Limitations of the Present Research and Future Directions}

Due to the use of cross-sectional data, the main limitation of this study concerns the causal direction of the proposed relationships. It cannot be ruled out that the relationship between national identification and perceived threats and gains may be bidirectional. Specifically, while stronger national identification can elicit stronger perceptions of threats over gains resulting from immigration, the reverse is also plausible. To address these causality issues, we examined an alternative indirect path leading from the perception of threats and gains through national identification to outgroup attitudes. While we found some support for the reverse model, the indirect effect found in the alternative model was weaker than the one found in the original model. This suggests that although the relationship between national identification and the perception of threats and gains may be reciprocal, the original model tested in this study receives more support than the reversed model in terms of both theory and our empirical results. Therefore, future research will benefit from examining the proposed model longitudinally.

As regards future directions, we call for further research which will advance our understanding of the role of perceived threats and gains and their interplay with national identification on the outgroup attitudes of majority members. We also welcome studies investigating the interrelations (independency vs. inverse relation) between immigration-related threats and gains in the context of outgroup attitudes. Also, research focusing on both personal and group dimensions of perceived threats and gains in the formation of outgroup attitudes is needed. We also encourage research examining the proposed models in other intergroup and immigration contexts, so as to deepen understanding of the factors involved in positive relations between majority and minority groups. 


\section{References}

Aberson, C. L., \& Gaffney, A.M. (2009). An integrated threat model of explicit and implicit attitudes. European Journal of Social Psychology, 39, 808-830.

Alhakami, A. S., \& Slovic'P. (1994). A psychological study of the inverse relationship between perceived risk and perceived benefit. Risk Analysis, 14, $1085-1096$.

Berry, J. W., Phinney, J. S., Sam, D. L., Vedder, P. (2006). Immigrant youth: Acculturation, identity, and adaptation. Applied psychology: An International Review, 55, 303-332.

Berry, J. (2012). Mutual intercultural relations in plural societies (MIRIPS).

Retrieved from http://www.victoria.ac.nz/cacr/research/mirips

Bizman, A., \& Yinon, Y. (2001a). Intergroup and interpersonal threats as determinants of prejudice: the moderating role of in-group identification. Basic and Applied Social Psychology, 23, 191-196.

Bizman, A., \& Yinon, Y. (2001b). Perceived threat and Israeli Jews' evaluations of Russian immigrants: the moderating role of Jewish and Israeli identity. International Journal of Intercultural Relations, 25, 691-704.

Branscombe, N. R., \& Wann, D. L. (1994). Collective self-esteem consequences of outgroup derogation when a valued social identity is on trial. European Journal of Social Psychology, 24, 641-657.

Cacioppo, J. T., Gardner, W. L., \& Berntson, G. G. (1997). Beyond bipolar conceptualizations and measures: The case of attitudes and evaluative space. Personality and Social Psychology Review, 1, 3-25. 
Engelbrekt, K., \& Nygren, B. (Eds.) (2014). Russia and Europe: building bridges, digging trenches. London, United Kingdom: Routledge.

Esses, V. M., Jackson, L. M., Dovidio, J. F., \& Hodson, G. (2005). Instrumental relations among groups: Group competition, conflict, and prejudice. In J. Dovidio, P. Glick, \& L. Rudman (Eds.), On the nature of prejudice. Fifty years after Allport (pp. 71-88). Malden: Blackwell Publishing.

European Union Agency for Fundamental Rights (2012). Data in focus report: Minorities as victims of crime. Retrieved from http://fra.europa.eu/sites/default/files/fra-2012-eu-midis-dif6_0.pdf

Hayes, A. F. (2013). Introduction to mediation, moderation, and conditional process analysis: A regression-based approach. New York: The Guilford Press.

Heinmueller, J., \& Hiscox, M. J. (2007). Educated preferences: Explaining attitudes toward immigration in Europe. International Organization, 61, 399-442. Hodson, G., Dovidio, J. F., \& Esses, V. M. (2003). Ingroup identification as a moderator of positive-negative asymmetry in social discrimination. European Journal of Social Psychology, 33, 215-233.

Jaakkola, M. (2009). Maahanmuuttajat suomalaisten näkökulmasta. Asennemuutokset 1987-2007 [Immigrants from the perspective of Finns. Change in attitudes 1987-2007]. Helsinki: City of Helsinki Information Centre.

Jasinskaja-Lahti, I., Liebkind, K., \& Solheim, E. (2009). To identify or not to identify? National disidentification as an alternative reaction to perceived ethnic discrimination. Applied Psychology: An International Review, 58, 105-128. LeVine, R. A., \& Campbell, D. T. (1972). Ethnocentrism. New York: Wiley. 
Larja, L., Warius, J., Sundbäck, L., Liebkind, K., Kandolin, I., \& Jasinskaja-Lahti, I. (2012). Discrimination in the Finnish labor market. An overview and a field experiment on recruitment. Helsinki, Finland: Ministry of Employment and Economy.

Mähönen, T. A., Jasinskaja-Lahti, I., Liebkind, K., \& Finell, E. (2011). Perceived importance of contact revisited: Anticipated consequences of intergroup contact for the ingroup as predictors of the explicit and implicit ethnic attitudes of youth. Group Processes \& Intergroup Relations, 14, 19-30.

Meeus, J., Duriez, B., Vanbeselaere, N., Phalet, K., \& Kuppens, P. (2009).

Examining dispositional and situational effects on outgroup attitudes. European Journal of Personality, 23, 307-328.

Meeus, J., Duriez, B., Vanbeselaere, N., \& Boen, P. (2010). The role of national identity representations in the relationship between in-group identification and out-group derogation: Ethnic versus civic representations. British Journal of Social Psychology, 49, 305-320.

Mlicki, P. P., \& Ellemers, N. (1996). Being different or being better? National stereotypes and identifications of Polish and Dutch students. European Journal of Social Psychology, 26, 97-114.

Mummendey, A., Klink, A., \& Brown, R. (2001). Nationalism and patriotism: national identification and out-group rejection. British Journal of Social Psychology, 40, 159-172.

Myers, T. A. (2011). Goodbye, listwise deletion: Presenting hot deck imputation as an easy and effective tool for handling missing data. Communication Methods and Measures, 5, 297-310. 
Phinney, J. S., \& Devich-Navarro, M. (1997). Variations in bicultural identification among African American and Mexican American adolescents. Journal of Research on Adolescence, 7, 3-32.

Pitkänen, P., \& Kouki, S. (2002). Meeting foreign cultures: a survey of the attitudes of Finnish authorities towards immigrants and immigration. Journal of Ethnic and Migration Studies, 28, 103-118.

Preacher, K. J., Rucker, D. D., \& Hayes, A. F. (2007). Addressing moderated mediation hypotheses: Theory, methods, and prescriptions. Multivariate Behavioral Research, 42, 185--227.

Puuronen, V. (2011). Rasistinen Suomi [Racist Finland]. Helsinki: Gaudeamus.

Reynolds, K. J., Turner, J. C., Haslam, S. A., Ryan, M. K., Bizumic, B., \& Subasic, E. (2007). Does personality explain in-group identification and discrimination? Evidence from the minimal group paradigm. British Journal of Social Psychology, 46, 517-539.

Riek, B. M., Mania, E. W., \& Gaertner, S. L. (2006). Intergroup threat and outgroup attitudes: A meta-analytic review. Personality and Social Psychology Review, $10,336--353$.

Schwartz, S. (2007). Universalism, values, and the inclusiveness of our moral universe. Journal of Cross-Cultural Psychology, 38, 711-728.

Sherif, M. (1966). Group conflict and cooperation. London: Routlege and Kegan Paul.

Simoila, R., Väistö, O., Nyman, J, \& Niemelä, A. L. (2011). Helsingin terveyden toimintaympäritön analyysi terveyskeskuksen strategian 2012-2014 valmistelun pohjaksi [Helsinki health environment analysis as a basis for preparation health centres' strategy for years 2012-2014]. Helsinki: City of 
Helsinki Health Centre. Retrieved from

http://www.hel.fi/wps/wcm/connect/52ae5d8047e1eba6adaeaf5e8d8a1cc7/To imitaymp\%C3\%A4rist\%C3\%B6n+analyysi+2011_nettiin.pdf?MOD=AJPER $\underline{\text { ES\&lmod }=-1466217692}$

Smith, A. D. (2001). Nationalism: Theory, ideology, history. Cambridge, United Kingdom: Polity Press.

Statistic Finland (2012). Nationality according to age and sex by region 1990-2012 (table). Retrieved from http://193.166.171.75/Dialog/varval.asp?ma=020_vaerak_tau_101_en\&ti=Na $\underline{\text { tionality+according+to+age }+ \text { and }+ \text { sex }+ \text { by }+ \text { region }+1990+\% 2 D+2012 \& p a t h=. .}$ /Database/StatFin/vrm/vaerak/\&lang=1\&multilang=en

Statistics Finland (2014). Foreign-language speakers account for 90 per cent of the population growth in 2013. Retrieved from http://tilastokeskus.fi/til/vaerak/2013/vaerak_2013_2014-03$\underline{21 \_ \text {tie_001_en.html }}$

Stephan, W. G., \& Stephan, C. W. (2000). An integrated threat theory of prejudice. In S. Oskamp (Ed.), Reducing prejudice and discrimination. The Claremont Symposium on applied social psychology (pp. 23-45). Mahwah: Lawrence Erlbaum Associates, Inc.

Stephan, W. G., Boniecki, K. A., Ybarra, O., Bettencourt, A., Ervin, K. S., Jackson, L. A., McNatt, P. S., \& Renfro, C. L. (2002). The role of threats in the racial attitudes of Blacks and Whites. Personality and Social Psychology Bulletin, $28,1242-1254$.

Stephan, W. G., Renfro, C. L., \& Davis, M. D. (2008). The role of threat in intergroup relations. In U. Wagner, L. R. Tropp, G. Finchilescu, \& C. 
Tredoux (Eds.), Improving intergroup relations. Building on the legacy of Thomas F. Pettigrew (pp. 55-72). Malden, MA: Blackwell.

Tajfel, H. \& Turner, J. (1979). An integrative theory of intergroup conflict. In M. A. Hogg \& D. Abrams (Eds.), Intergroup relations (pp. 94-109). Psychology Press: Taylor \& Francis Group.

Tausch, N., Tam, T., Hewstone, M., Kenworthy, J., \& Cairns, E. (2007). Individuallevel and group-level mediators of contact effects in Northern Ireland: The moderating role of social identification. British Journal of Social Psychology, $46,541-556$.

Tropp, L. R., \& Mallett, R. K. (2011). Moving beyond prejudice reduction: Pathways to positive intergroup relations. Washington, DC: American Psychological Association.

Turner, J. C., \& Reynolds, K. J. (2001). The Social Identity Perspective in intergroup relations: theories, themes, and controversies. In R. Brown, \& S. Gaertner (Eds.), Blackwell handbook of social psychology: intergroup processes (pp. 133-152). Malden: Blackwell Publishers.

Van Reekum, R., Duyvendak, J. W., Bertossi, C. (2012). National models of integration and the crisis of multiculturalism: a critical comparative perspective. Patterns of Prejudice, 46, 417-426.

Velasco González, K., Verkuyten, M., Weesie, J., \& Poppe, E. (2008). Prejudice towards Muslim in the Netherlands: testing integrated threat theory. British Journal of Social Psychology, 47, 667-685. 
Table 1

Means and Standard Deviations of the Variables Used in This Study and Correlations Between These Variables $(N=335)$

\begin{tabular}{|c|c|c|c|c|c|c|c|c|c|c|c|}
\hline \multirow[b]{2}{*}{ Variable } & \multirow[b]{2}{*}{ Mean $(S D)$} & \multicolumn{10}{|c|}{ Pearson's correlations } \\
\hline & & 1 & 2 & 3 & 4 & 5 & 6 & 7 & 8 & 9 & 10 \\
\hline 1. Age & $45.87(13.75)$ & 1 & -.01 & $-.11^{*}$ & .04 & -.02 & -.02 & -.03 & .03 & -.08 & -.09 \\
\hline 2. Gender & --- & & 1 & -.02 & .08 & .06 & $.11^{*}$ & -.03 & .06 & .04 & .03 \\
\hline 3. Years of education & $14.28(4.78)$ & & & 1 & -.09 & $.19^{* *}$ & $.14^{* *}$ & $.22^{* * * *}$ & $.15^{* *}$ & $.21^{* * * *}$ & $.19^{* *}$ \\
\hline 4. National identification & $4.66(0.64)$ & & & & 1 & $-.19^{* *}$ & $-.15^{* *}$ & $-.21^{* * *}$ & $-.19^{* *}$ & $-17^{* *}$ & $-.24^{* * *}$ \\
\hline 5. $\mathrm{T} / \mathrm{G}$ index & $0.14(0.61)$ & & & & & 1 & $.93^{* * * *}$ & $.89^{* * *}$ & $.92^{* * *}$ & $.94^{* * *}$ & $.60^{* * *}$ \\
\hline 6. Symbolic $\mathrm{T} / \mathrm{G}$ index & $0.34(0.72)$ & & & & & & 1 & $.71^{* * *}$ & $.90^{* * *}$ & $.86^{* * *}$ & $.54^{* * *}$ \\
\hline 7. Realistic $\mathrm{T} / \mathrm{G}$ index & $-0.06(0.60)$ & & & & & & & 1 & $.81^{* * *}$ & $.89^{* * *}$ & $.60^{* * *}$ \\
\hline 8. Individual $\mathrm{T} / \mathrm{G}$ index & $0.07(0.61)$ & & & & & & & & 1 & $.76^{* * *}$ & $.54^{* * *}$ \\
\hline 9. Group $\mathrm{T} / \mathrm{G}$ index & $0.20(0.69)$ & & & & & & & & & 1 & $.60^{* * *}$ \\
\hline 10. Outgroup attitudes & $3.38(0.98)$ & & & & & & & & & & 1 \\
\hline
\end{tabular}

Note. ${ }^{*} p<.05 .{ }^{* *} p<.01 .{ }^{* * *} p<.001 . \mathrm{T} / \mathrm{G}$ index $=$ threats/gains index. 
Table 2

Regression Analysis on the Predictors of the Majority Members' Attitudes Towards Russian Immigrants in Finland $(N=335)$

\begin{tabular}{lll}
\hline Predictor & $B$ & $S E$ \\
\hline Constant & $3.39^{* * *}$ & .21 \\
Age & 0.00 & .00 \\
Gender & 0.01 & .09 \\
Years of education & 0.01 & .01 \\
National identification (NI) & $-0.23^{*}$ & .07 \\
Threats/gains index (T/GI) & $0.90^{* * *}$ & .07 \\
NI x T/GI & 0.16 & .12 \\
\hline$R^{2}$ & .39 & \\
$F$ change for $R^{2}$ & $35.03^{* * *}$ & \\
\hline Note. ${ }^{*} p<.01 .{ }^{* * * *} p<.001$. &
\end{tabular}

Note. ${ }^{*} p<.01 .{ }^{* * * *} p<.001$. 
Table 3

Model Coefficients for the Outgroup Attitudes Simple Mediation Analysis with One Covariate- Years of Education $(N=335)$

\begin{tabular}{|c|c|c|c|c|}
\hline \multirow[b]{2}{*}{ Predictor } & \multicolumn{2}{|c|}{$\begin{array}{l}\text { Threats/gains } \\
\text { index (Me) }\end{array}$} & \multicolumn{2}{|c|}{$\begin{array}{c}\text { Outgroup } \\
\text { attitudes (DV) }\end{array}$} \\
\hline & $B$ & $S E$ & $B$ & $S E$ \\
\hline Constant & $0.54^{\dagger}$ & .29 & $4.14^{* * *}$ & .38 \\
\hline Age & 0.00 & .00 & 0.00 & .00 \\
\hline Gender & 0.09 & .07 & 0.01 & .09 \\
\hline Years of education & $0.02^{* *}$ & .01 & 0.01 & .01 \\
\hline National identification (X) & $-0.17^{* * *}$ & .05 & $-0.19^{* *}$ & .07 \\
\hline Threats/gains index (Me) & --- & --- & $0.90^{* * * *}$ & .07 \\
\hline$R^{2}$ & .07 & & .39 & \\
\hline$F$ change for $R^{2}$ & $6.33^{* * *}$ & & $41.58^{* * *}$ & \\
\hline
\end{tabular}

Note. ${ }^{\dagger} p<.10 .{ }^{* *} p<.01 .{ }^{* * * *} p<.001 . \mathrm{X}=$ independent variable, $\mathrm{Me}=$ mediator variable, $\mathrm{Y}=$ dependent variable. 

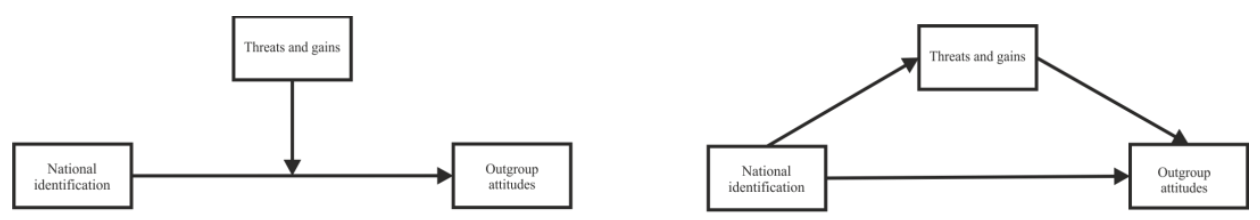

Figure 1. Hypothesised moderation (left) and mediational (right) models of the relationship between national identification and outgroup attitudes among majority Finns.
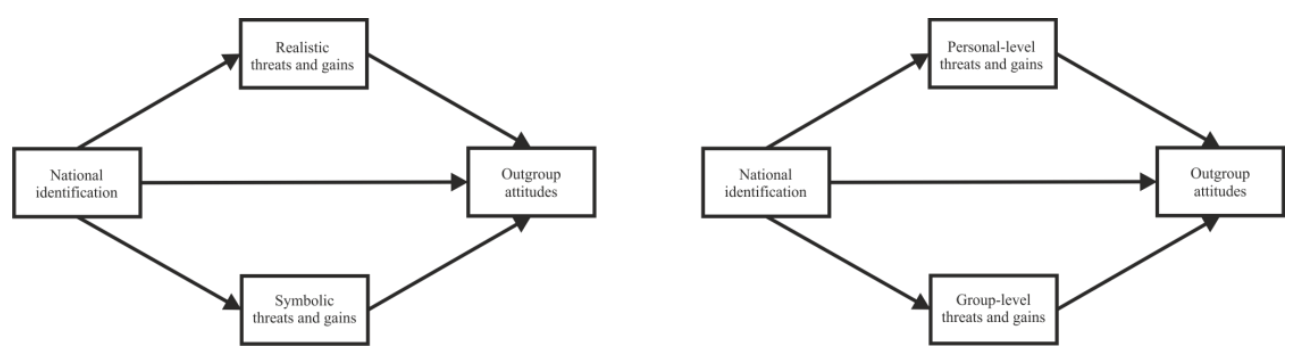

Figure 2. Hypothesised mediational post-hoc models of the relationship between national identification and outgroup attitudes among majority Finns. 